\title{
WYMIANA CIAŁA NA OBRAZ. PRÓBA POCHWYCENIA DROGI RZECZY OD MATERII DO WSPOMNIENIA
}

BRONKA NOWICKA

Wydział Malarstwa Akademii Sztuk Pięknych w Krakowie Department of Painint, Academy of Fine Arts in Cracow (Poland) bronkanowicka7@gmail.com

\section{BOLESNOŚĆ RZECZY}

Od czterech lat badam relacje zachodzące między ludźmi a rzeczami. Udokumentowałam kilkaset historii relacji człowiek - rzecz. Odbyłam szereg spotkań z osobami w różnym wieku, reprezentującymi różnorodne środowiska i światooglądy ${ }^{1}$ W ten sposób powstało archiwum zawierające fotografie rzeczy oraz zapis audio rozmów i monologów relacjonujących związki właścicieli z ich rzeczami, które określam jako:

- antropomorfizowane i personifikowane, między innymi: zabawki, artefakty i ekofakty, które nie powstały jako zabawki, ale stały się nimi zgodnie z intencją posiadacza, na przykład: pałka do ucierania ciasta staje się w czasie wojny lalką, kamień to przyjaciel i powiernik osoby samotnej;

- sentymentalne - pamiątki, fetysze, artefakty i ekofakty wywołujące asocjacje $\mathrm{z}$ istotnymi momentami życia właściciela;

- uobecniające zmarłych, na przykład: maszyna do pisania, laska i radio uobecniają ojca, kontakt $z$ konkretnymi przedmiotami daje poczucie obcowania $\mathrm{z}$ nieobecnym;

1 Wśród moich rozmówców znaleźli się, między innymi, pensjonariusze domów spokojnej starości, pensjonariusze dziennych domów pobytu dla osób upośledzonych umysłowo, artyści (głównie pisarze, tłumacze, plastycy), gospodynie domowe, przedstawiciele wielu zawodów: księgowi, leśniczowie, przedszkolanki, nauczyciele, instruktorzy teatralni, sprzedawcy itd. 
- dokumentujące upływ czasu, zdarzenia, stany emocjonalne;

- zapa mięta ne - nieistniejące już jako materia, a jedynie jako jej obrazy we wspomnieniu;

- jeszcze istniejące, ale skazane na unicestwienie, mające ulec zniszczeniu celowo dokonanemu przez właścicieli.

Co mnie dotyka, boli, interesuje w rzeczy i jej relacji z człowiekiem? Mogę założyć, że każda rzecz ma w sobie - ze względu na obecność w świecie człowieka - pewien wymiar ludzki. Oznacza to, że świat rzeczy stanowi theatrum, w którym odbija się świat tego, co ludzkie. Interesuje mnie to, co ludzkie - tym chcę się zajmować w mojej twórczości. Jednak na pierwszoplanowego bohatera moich - zakorzenionych w tym, co dokumentalne - prac wybieram rzecz. Dlaczego? Ponieważ poczucie tragizmu wywoływane przez obrazy rzeczy uważam za równie - jeśli nie bardziej - dojmujące niż to, które manifestuje się bezpośrednio przez ludzki los i śmiertelne ciało. Tragizm rzeczy zdaje się polegać na tym, że przedłuża ona czyjeś lub czegoś życie zaledwie o kilka kroków. Rzecz, która przeżywa swojego właściciela, staje się jego reprezentantem, ale też każda rzecz, która w utrwala to, co minione, w końcu umiera. Zanim jednak materia zniszczy się i rozpadnie - pamięta, symbolizuje, uobecnia. Mówiąc o duchowym poprzez materialne, o żywym przez martwe, traktując rzecz jako bohatera częściej widocznego w materii dzieła niż sam człowiek - jako bohatera równorzędnego - mogę opowiadać o nim bez patosu wynikającego z bezpośredniości przedstawień.

\section{RELACJE CZŁOWIEK - RZECZ. PRZYKŁADY Z ARCHIWUM}

Trzydzieści lat temu drewniany koralik był psem, prowadzanym na nitce-smyczy, czesanym za pomocą szczotki do zębów, kąpanym, regularnie karmionym. Koralik ma na imię Sonia. Używam słowa „ma” zamiast „miał”, ponieważ uczulona na sierść właścicielka, której - gdy była dzieckiem - zastępował psa, ciągle tak go nazywa. Dziś koralik nie jest już animizowany, ale ciągle traktuje się go $\mathrm{z}$ atencją, o której zaświadcza sposób przechowywania - w ozdobnym pudełku z miękką wyściółką.

Bransoletka była kiedyś widelcem, który z kolei był kiedyś grzebieniem pełniącym jednocześnie funkcję narzędzia do wyciągania klusek gotowanych w czajniku. Druga wojna światowa generowała absurdalne konglomeraty zastosowań rzeczy: „Myśmy się czesali widelcem, kluski gotowali 
w czajniku” - wspomina pierwsza właścicielka widelca. „Jak się która, bo nas było cztery, nie uczesała w porę, czekała, aż druga wyciągnie tym naszym grzebieniem cały makaron z czajnika. Jak czajnik przestawał być garnkiem na kluski, dopiero się wstawiało wodę na herbatę" ${ }^{2}$. Bransoletka zrobiona z widelca należy dziś do wnuczki kobiety.

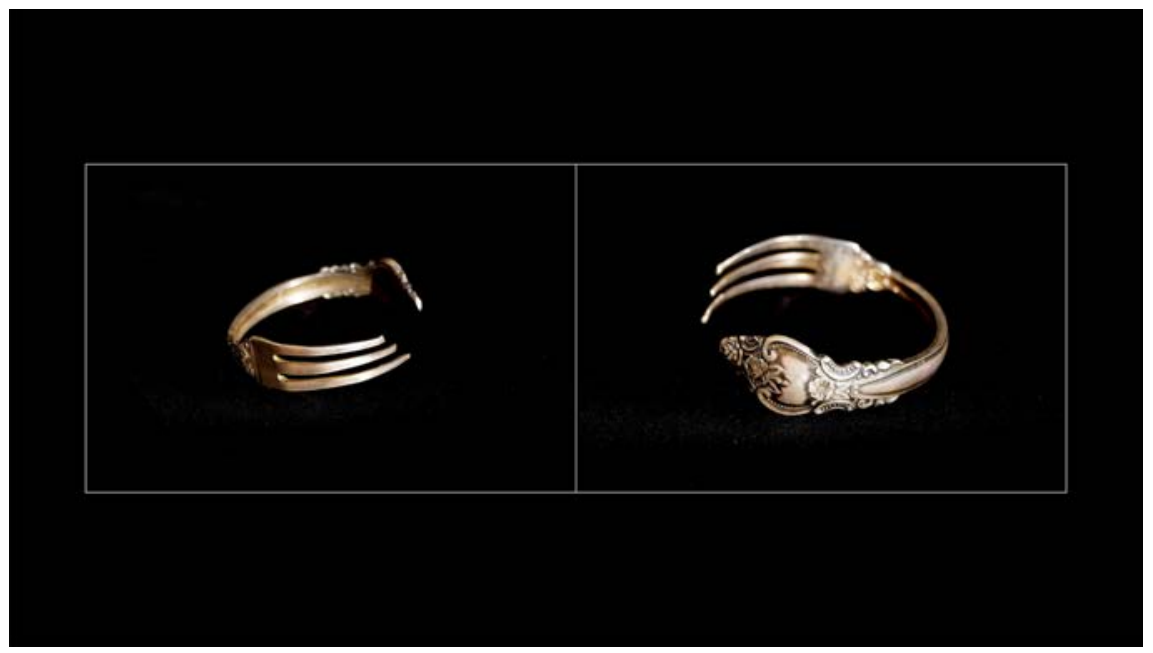

Bransoletka-widelec. Archiwum dokumentujące relacje człowiek-rzecz (fot. autorki)

Mydła należące do tłumaczki sztuk teatralnych biorą udział w rytuale dyktowanym nerwicą natręctw. Każde z czterdziestu dwóch mydeł służy do mycia tylko jednej z czterdziestu dwóch części, na które tłumaczka symbolicznie dzieli swoje ciało. Są mydła używane tylko we wtorek, tylko w czwartek, jedynie w sobotę. Przynależność kostki do określonego dnia tygodnia określa jej smak: jedne smakują jak niedziela, inne jak środa. Przynależność do określonych dni tygodnia może określać również ciągle zmieniający się kształt mydeł. W relacji tłumaczki z mydłami choroba miesza się z poezją.

Zasuszone, zużyte torebki herbaty, na które nanoszone są notatki dotyczące dat, pór dnia i zdarzeń sąsiadujących z czynnością picia herbaty,

2 Cytat pochodzi z wypowiedzi wnuczki pierwszej właścicielki widelca. 
stanowią swoisty pamiętnik. Zużyte torebki herbaciane, wypreparowane z fusów i wypełnione zdjęciami ludzi, z którymi piło się herbatę, stają się estetyzującym dokumentem spotkań.

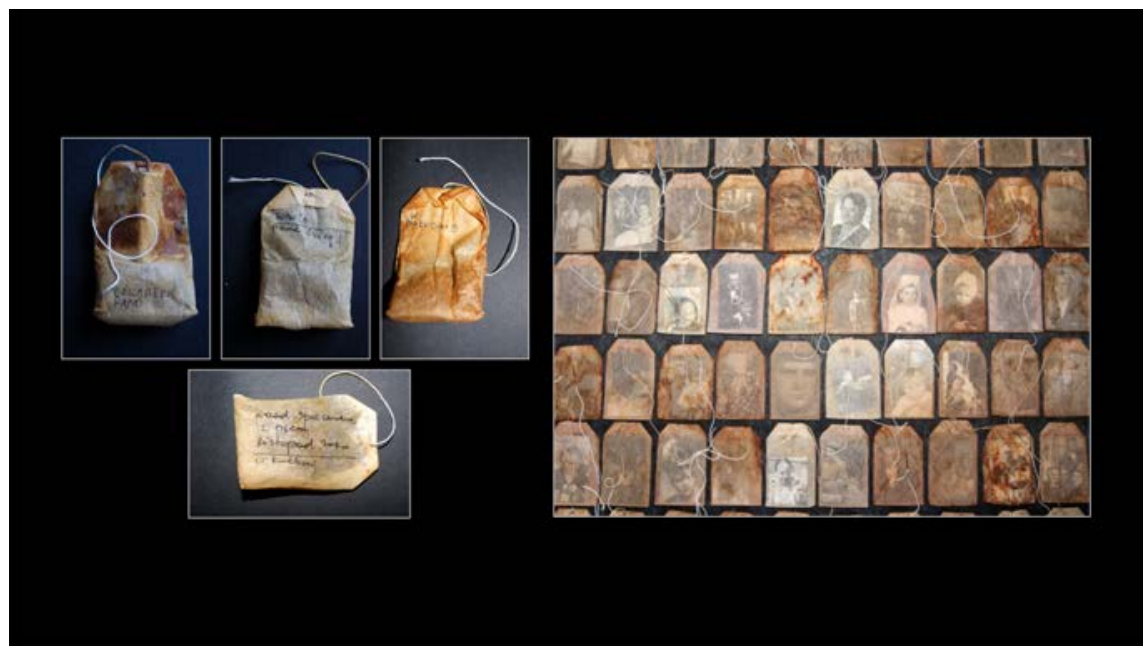

Po lewej: torebki herbaty - notatniki. Po prawej: fragment pracy Bronki Nowickiej Ludzie, z którymi piłam herbatę (technika własna) (fot. autorki)

Granatowy guzik należy do dziewięćdziesięciosześcioletniej kobiety. Gdy miała dziewięć lat, obracała go w palcach na pogrzebie matki. Kobieta twierdzi, że dotykanie guzika oderwanego od płaszcza należącego do zmarłej pomagało przetrwać trudne chwile, nie tylko te związane ze śmiercią bliskiej osoby. Podobną wspierającą funkcję pełniła lalka, przytulana przez dziewczynkę, która razem z siostrami i matką przeczekiwała bombardowania podczas II wojny światowej w jednym z grobowców kieleckiego cmentarza. 


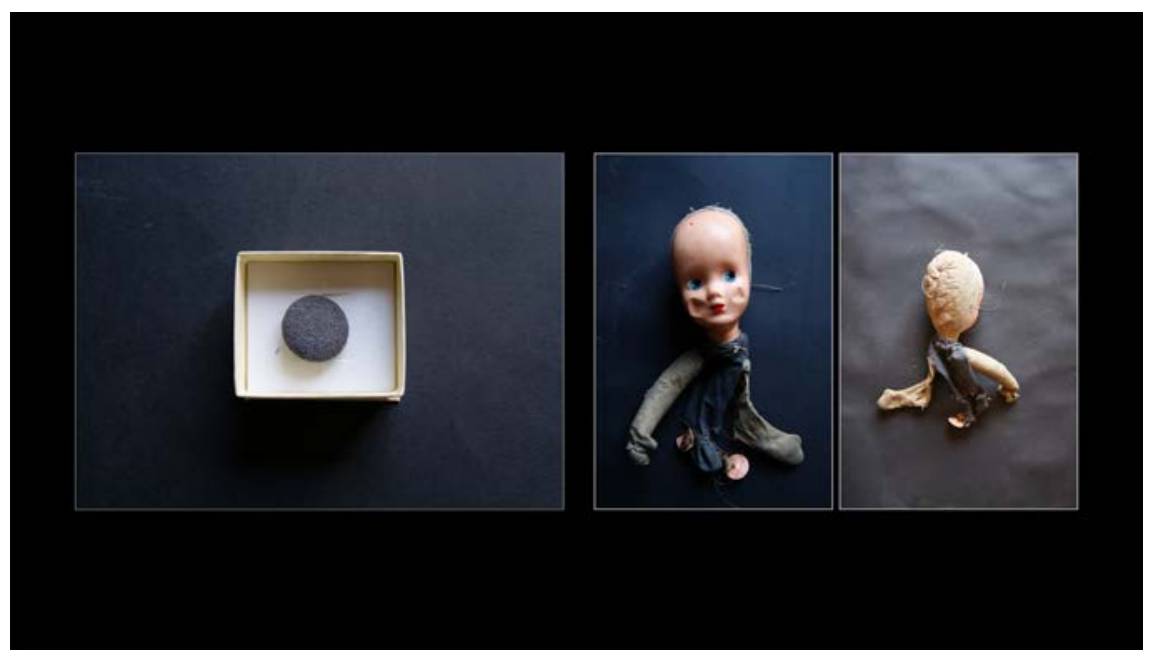

Guzik zpłaszcza zmarłej matki. Lalka przytulana w grobowcu. Archiwum dokumentujące relacje człowiek - rzecz (fot. autorki).

Słoik po gołąbkach już dwanaście lat więzi „demona” malarki. Na fotografii umieszczonej w słoiku widoczna jest twarz artystki z okresu, gdy była „opętana”, to znaczy prowadziła intensywne życie o trudnej do zniesienia amplitudzie emocjonalnej. Zamknięcie wizerunku w słoiku było wówczas symbolicznym zakończeniem pewnego etapu, znakiem stabilizacji. Dziś, gdy malarka potrzebuje stymulacji, pożywki do pracy, emocjonalnej erupcji, lekko odkręca wieczko słoika. Słoik „z demonem” można nazwać regulatorem siły natchnienia.

\section{RZECZY SKAZANE NA UNICESTWIENIE}

W prowadzonych badaniach, na kanwie których powstają moje prace artystyczne, szczególną uwagę poświęcam rzeczom, które kończą egzystencję jako materia i zaczynają żyć jako wspomnienie, a więc przechodzą drogę od masywnej materii do efemerycznego obrazu. Do grupy tej należą:

- zabawki, których - mimo sentymentu - należy się pozbyć, ponieważ osobie dorosłej nie wypada ich mieć; 
- rozmaite rzeczy należące do bliskich zmarłych; rzeczy te są niszczone $\mathrm{z}$ różnych powodów, najczęstszy to chęć odcięcia się od bólu związanego z odejściem bliskiej osoby;

- rzeczy, których unicestwienie stanowi symboliczne zerwanie z przeszłością czy wyswobodzenie z niepożądanej relacji.

Obserwowałam rozstania właścicieli ze wspomnianymi rzeczami. Niezależnie od tego, czy rozstania te dokonywały się poprzez wyrzucenie, spalenie, czy zakopanie w ziemi, przebiegały zazwyczaj przy udziale emocji, po których następowały cykle wspomnień ogniskujących się wokół unicestwionych rzeczy. Reminiscencje pojawiały się jeszcze na długo po ich dematerializacji, wykazując dużą siłę i częstotliwość niezależnie od tego, czy właściciel oglądał rzeczy tuż przed rozstaniem z nimi, czy raczej wolał pamiętać je takimi, jakimi widział je kiedyś.

Kolekcjonując wspomnienia dotyczące rzeczy już nieistniejących lub takich, które niebawem miały zakończyć egzystencję, zaczęłam poszukiwać metody obrazowania drogi biegnącej od materii do wspomnienia. Szukałam medium będącego w stanie dokumentować rzeczy, zaświadczać w najbardziej wiarygodny sposób o ich istnieniu, kształcie, fakturze, kolorze, rodzaju materii, w której lub z której powstały, a jednocześnie medium sięgającego głębiej niż fotografia czy rejestracja filmowa. Dlatego zdecydowałam się poddać grupę skazanych na unicestwienie rzeczy badaniu promieniami $\mathrm{X}$ w tomografie komputerowym.

\section{TOMOGRAFIKI ${ }^{3}$ RZECZY}

Do tomografu trafiły: różnego typu stare zabawki i inne rzeczy związane z dzieciństwem właścicieli; rzeczy po zmarłych - ich torby, walizki, buty, worki $z$ ubraniami, półki z bibelotami, których konfiguracje nie były w najmniejszym stopniu zmieniane przy wkładaniu do tomografu; rzeczy stanowiące wyposażenie starych (z różnych przyczyn opuszczonych przez właścicieli) domów i mieszkań; rzeczy należące kiedyś do dawnych partnerów, małżonków, przyjaciół właścicieli.

3 „Tomografiki” - neologizm utworzony przeze mnie na potrzeby określania statycznych obrazów pozyskanych dzięki odpowiedniemu opracowaniu skanów wykonanych w tomografie komputerowym. 


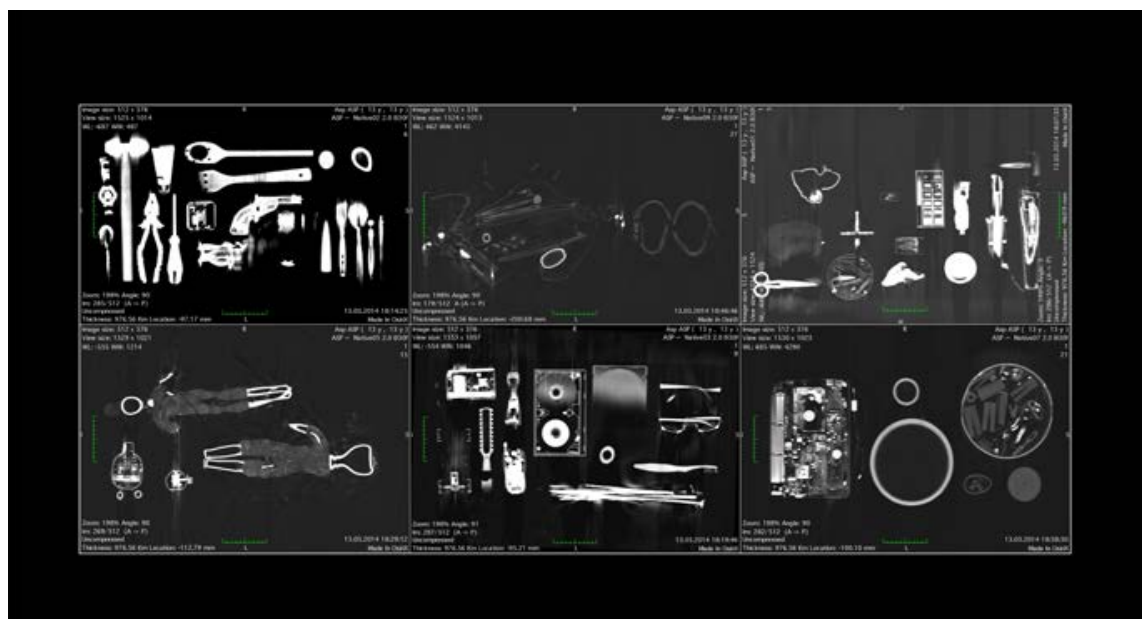

Rzeczy skazane na unicestwienie. Tomogramy. Autorka tomografiki: Bronka Nowicka

Pozyskane w tomografie komputerowym obrazy rzeczy z kilku powodów wydały mi się adekwatne do budowania narracji zarówno o istniejącej materii, jak i o jej wspomnieniu. Dzięki oprogramowaniu tomografu komputerowego z każdego macierzystego skanu materii, zarówno organicznej, jak i nieorganicznej, można pozyskać trójwymiarową rekonstrukcję prześwietlanego obiektu. Obrazy te zaświadczają nie tylko o wyglądach rzeczy, ale też o prawdziwości ich egzystencji, potwierdzonej poprzez badanie urządzeniem medycznym. Dzięki tomografowi można precyzyjnie ustalić wszystkie wielkości badanego obiektu, a także - na podstawie charakterystyki pozyskanego obrazu - wyróżnić rodzaje materii, z których składa się obiekt: plastik, drewno, metal, papier idp.

Ważne było dla mnie to, że wygenerowany za pomocą tomografu obraz rzeczy nigdy nie traci swoich wartości dokumentalnych. Dokumentalność, odniesienie do realnego bytu, wydają mi się szczególnie istotne, gdy powstające prace artystyczne dotyczą kondycji człowieka.

Promienie X przenikają przez materię. Możliwości penetracyjne urządzenia sprawiają, że każdy pozyskany za jego pomocą obraz materii może być rozwarstwiany. Dzięki możliwości rozbierania obrazu z kolejnych warstw mogłam budować skojarzenia związane z degradacją wspomnień, procesem zapominania. 


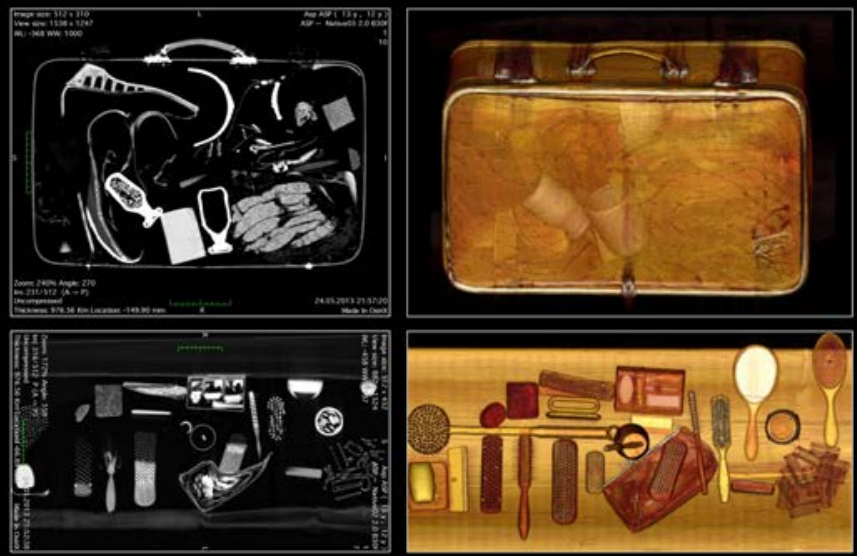

Rekonstrukcje 3D skanowanych rzeczy. Tomogramy. Autorka tomografiki: Bronka Nowicka
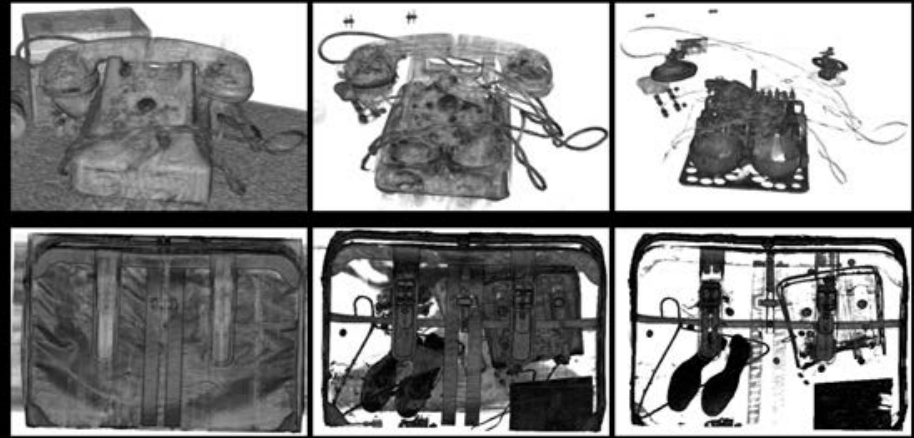

Destrukcje materii. Tomogramy. Autorka tomografiki: Bronka Nowicka 
Oprogramowanie tomografu posiada szereg funkcji wykorzystywanych przy diagnozowaniu poszczególnych partii ludzkiego ciała. Używając tych funkcji do kształtowania obrazów materii nieorganicznej, mogłam uzyskiwać różnorodne poetyki obrazu: od budzących skojarzenia z wielokolorowym, mocno kontrastowym pop-artem, po delikatne, szkicowe, wywołujące asocjacje z klasycznymi technikami graficznymi.

Możliwości penetracyjne tomografu miały też wpływ na poszerzenie zasobu mojej kolekcji wspomnień zbieranych od właścicieli skanowanych rzeczy. Każdą grupę artefaktów przeznaczonych do zniszczenia transportowałam do pracowni radiologicznej, poddawałam prześwietleniu i zwracałam właścicielowi, który - zgodnie z wcześniejszym zamierzeniem - niszczył je. Charakterystyczne było to, że właściciel nie chciał już kontaktować się z rzeczami w ich fizycznym wymiarze, ale nie miał nic przeciwko oglądaniu ich skanów. Zupełnie jakby cielesność rzeczy, na przykład rzeczy po zmarłych, miała wywoływać większy ból niż obrazy tychże samych rzeczy. Dzięki możliwości zobrazowania wnętrza przedmiotów przechowujących rzeczy (paki, worki, szuflady, skrzynie, walizki itp.) właściciele pierwszy raz od wielu lat oglądali zawartość pudełek kryjących artefakty z dzieciństwa czy zawartość walizek należących do zmarłych bliskich. Obszar wzruszających wspomnień poszerzał się pod wpływem kontaktu z obrazem rzeczy - zapomnianych, a teraz odnalezionych w pamięci kredek, taśm z ulubionymi piosenkami, klisz z bajkami rzutowanymi kiedyś na ekran za pomocą projektora, przyborów toaletowych dostrzeżonych w torbie zmarłej matki, która przed śmiercią - nosząc je przy sobie - musiała zdawać sobie sprawę, że w każdej chwili może znaleźć się w szpitalu.

Dzięki skontaktowaniu właścicieli z obrazami unicestwionych rzeczy dokumentowałam kolejne wspomnienia. Wyrażające je słowa stanowią (jako zapis audio oraz graficznie podany tekst) jedną z warstw moich prac. 


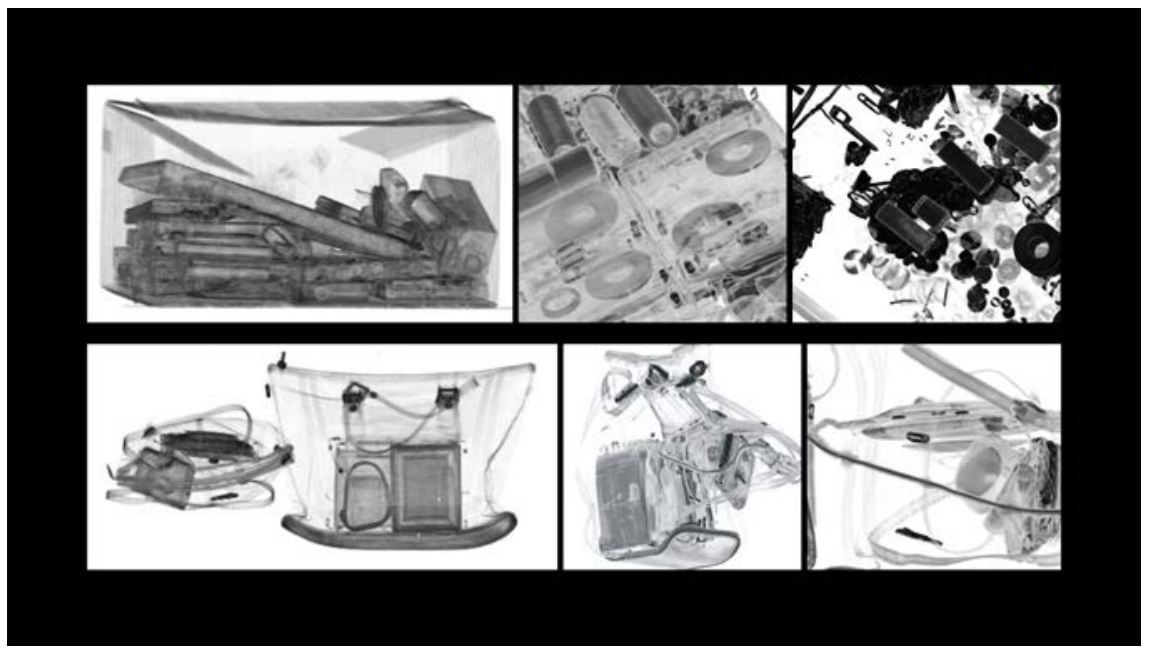

Rzeczy skazane na unicestwienie. Tomogramy. U góry: pudło zawierające m.in. taśmy magnetofonowe, klisze z bajkami. Na dole: torba należaca do zmarłej matki. Autorka tomografiki: Bronka Nowicka

\section{TOMOVIDEO ${ }^{4}$}

Szanse na sugestywne zobrazowanie drogi rzeczy od materii do wspomnienia stały się jeszcze większe, gdy odkryłam filmowe możliwości tomografu komputerowego, które w diagnozowaniu medycznym wykorzystuje się sporadycznie i w celach innych niż budowanie narracji. Dzięki tomografowi komputerowemu i towarzyszącemu mu oprogramowaniu można pozyskiwać r u ch o me obrazy zeskanowanej materii: rejestrować ich płynny ruch obrotowy wokół dowolnej osi, zdejmowanie i nakładanie poszczególnych warstw odpowiadających warstwom zeskanowanej rzeczy. Niektóre operacje możliwe do wykonania w obrębie skanu przypominają filmowe zabiegi inscenizacyjne: najazd kamery na obiekt, użycie zoomu, jazdę towarzyszącą

4 Tomovideo - neologizm stworzony przeze mnie na potrzeby określenia ruchomych obrazów oraz sekwencji obrazów pozyskanych poprzez odpowiednie opracowanie skanów (za pomocą programu komputerowego przynależącego do CT). 
obiektowi będącemu w ruchu, panoramowanie poziome, pionowe i poprzeczne, rejestrację obiektu z wysięgników czy steadicamu.

Ruchomy obraz lepiej niż szereg obrazów statycznych oddaje procesy przekształceń następujących w czasie. Dzieje się tak, ponieważ zawiera on zarejestrowany czas, który jest jednym z komponentów takiego obrazu. Ciąg ruchomych obrazów wydaje się też adekwatny do oddania tego, co zapamiętane - obrazy w ruchu czy film stanowią bowiem aktualną metaforę pamięci. Aktualną, ponieważ metafory te zmieniały się na przestrzeni wieków; były nimi: gliniana tabliczka, woskowa tabliczka, pismo, fonograf, fotografia itd. ${ }^{5}$

Dzięki ruchowi obrazu (i wewnątrz obrazu) mogłam kreować środki stylistyczne inspirowane procesami zachodzącymi w pamięci: powtarzalność ruchomego motywu przy jednoczesnym wprowadzaniu w jego obszar pewnych zmiennych może nawiązywać do zasady wywoływania wspomnień. Większość psychologów badających pamięć twierdzi, że wspominając, nie odwołujemy się do pierwowzoru zapamiętanego obrazu, ale to ostatniej kopii, która została utworzona przez przypomnienie.

Przypominając sobie coś, tworzymy ślad neuronowy, a następnym razem, gdy pozornie przypominamy sobie to samo, w rzeczywistości zostaje zaktywowany ślad, który powstał najpóźniej. Wspomnienia, również te najstarsze, podróżują, w miarę upływu czasu, w naszej tkance mózgowej, lecz wciąż od nowa towarzyszą im kolejne kopie. Zgodnie z tą teorią, gdy wracamy myślami do pierwszego wspomnienia, sprawiamy, że obwód neurologiczny naszej pamięci zamyka się w osobliwy sposób - najstarsze staje się na chwilę najnowszym, pierwsze ostatnim ${ }^{6}$.

Jeśli więc ktoś myślał dwieście razy o lalce z dziecięcych lat, to jego kolejne wspomnienie tej zabawki będzie dwieście pierwszą kopią pierwotnie zarejestrowanego obrazu, który z każdym wspomnieniem został poddany

5 Douve Draaisma, profesor nadzwyczajny historii psychologii na Uniwersytecie w Groningen, poświęcił zagadnieniu zmienności metafor wartą polecenia książkę pod tytułem Machina metafor. Historia pamięci, tłum. R. Pucek, Warszawa 2009.

6 D. Draaisma, Fabryka nostalgii. Ofenomenie pamięci wieku dojrzałego, tłum. E. Jusewicz-Katler, Wołowiec 2010, s. 6. 
jakiejś modyfikacji, zależnej na przykład od emocjonalnego stanu, w którym znajdował się wspominający w chwili wspominania.

Dysponując ruchomym obrazem o poetyce wzbudzającej skojarzenia z wyobrażeniem pamięci, aktu zapamiętywania oraz tego, co zostaje zapamiętane, mogłam wprowadzić do tworzonych tomovideo monologi właścicieli wspominających swoje rzeczy w sposób oparty na logicznej podstawie.

Użycie języka jako zasady organizującej następstwo obrazów koresponduje $\mathrm{z}$ faktami naukowymi potwierdzającymi koincydencję między językiem a pamięcią. Kiedy człowiek (dziecko) staje się istotą językową, wspomnienia zaczynają nabierać innego charakteru, ściśle powiązanego z wewnętrznym monologiem i komunikacją werbalną. Wspomnienia nie są już tylko obrazami, zaczynają przybierać postać scen i epizodów (terminologia związana $\mathrm{z}$ psychologią pamięci jest identyczna $\mathrm{z}$ nomenklaturą używaną na polu kinematografii) ${ }^{7}$.

\section{OBRAZ RZECZY COFA CZAS}

Dzięki moim badaniom i zainteresowaniu tomografem komputerowym dane mi było przejść drogą między materią a jej obrazem w pamięci w odwrotnym, niż omówiony wyżej, kierunku. Na pierwszą sesję tomograficzną zabrałam moją starą zabawkę - misia. Prześwietlenie promieniami X wykazało obecność piasku w jego uchu. Piasek ten mógł pochodzić jedynie $\mathrm{z}$ dwóch miejsc - $\mathrm{z}$ podwórka domu moich dziadków lub podwórka domu rodziców.

Pomyślałam: nie ma już tych domów. Nie ma też większości ludzi, którzy w nich mieszkali. Nie ma tamtych piasków, ale w uchu mojego ponad trzydziestoletniego misia są ziarna pochodzące z któregoś z nich. Odzyskać je - to jak cofnąć czas. Poddałam misia operacji, którą wykonał profesjonalny chirurg plastyk. Doktor wydobył z ucha misia zbrylony kurz, drewienko pochodzące prawdopodobnie ze struganej kredki i kilkanaście ziaren piasku. W ten sposób to, co egzystowało jedynie we wspomnieniu, znów objawiło się pod postacią materii.

7 Zainteresowanych tą tematyką odsyłam do książki D. Draaisma Księga zapominania, tłum. R. Pucek, Warszawa 2012. 


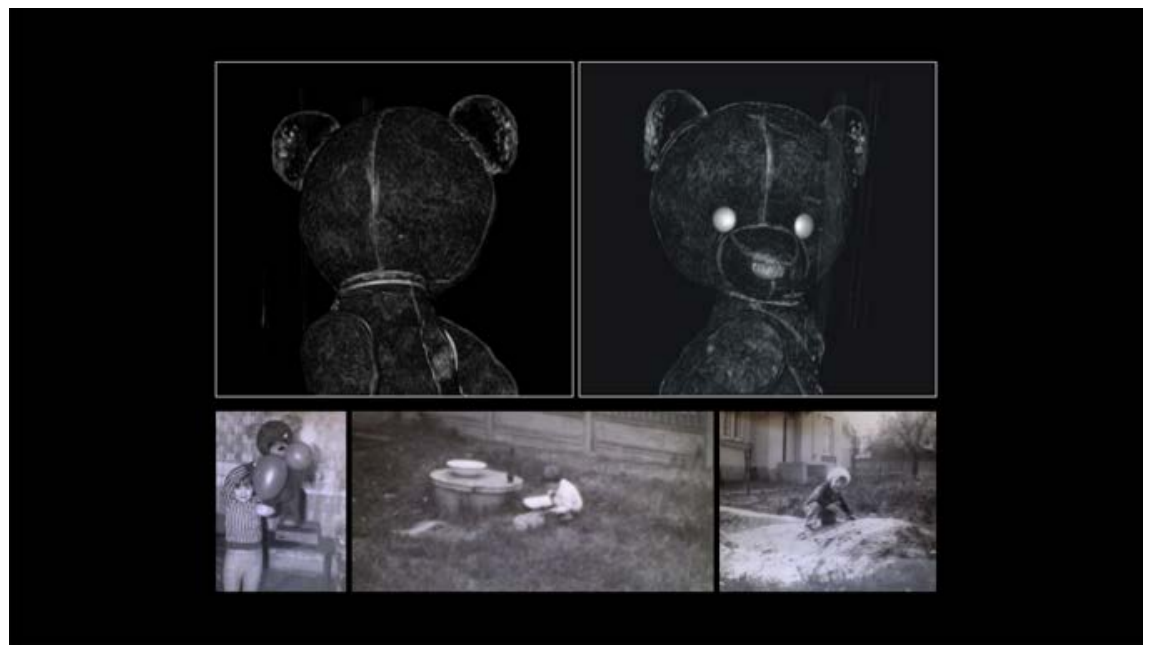

U góry: miś z piaskiem w uszach (fot. autorki). Na dole: autorka z misiem; przydomowe piaskownice (fot. z rodzinnych zbiorów)

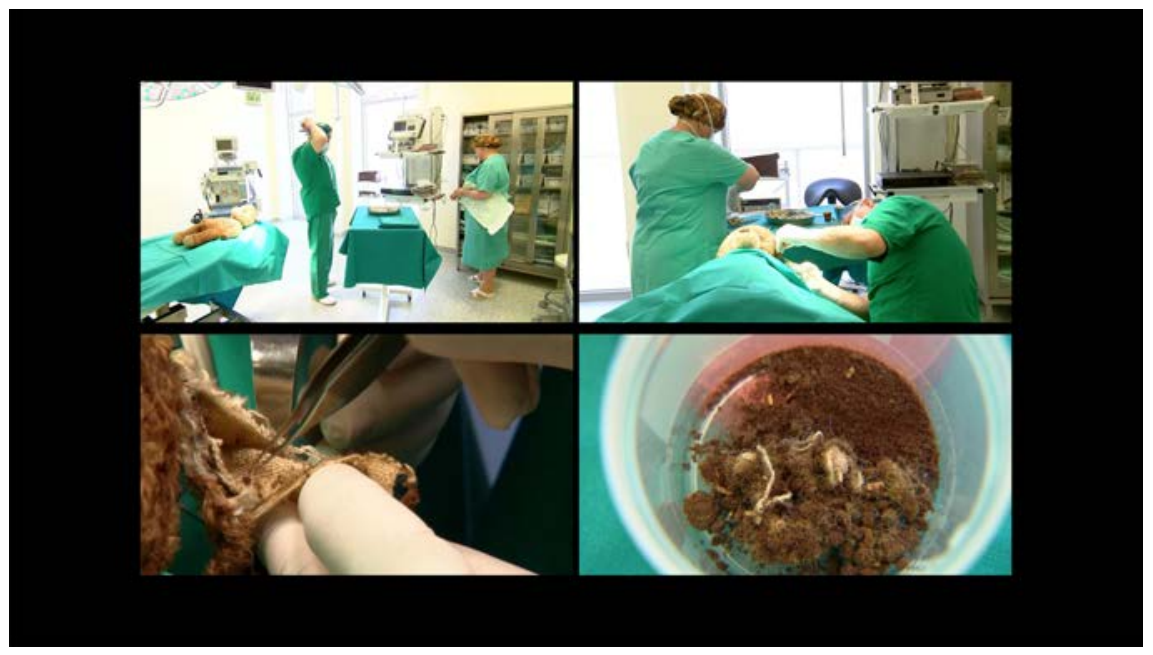

Operacja misia. Kadry z video Znalazłam mój piasek (fot. autorki) 
Poznając możliwości tomografu, posiadając umiejętność samodzielnego opracowywania tomogramów dzięki opanowaniu obsługi specjalistycznego oprogramowania medycznego, szukając inspiracji na terenie psychologii pamięci i neurologii, odkryłam nowe medium na terenie video art $^{8}$ i poetykę adekwatną do snucia narracji o przechodzeniu od materialnego do wspominanego.

8 Na terenie sztuki promienie X wykorzystują m.in. następujący artyści: Nick Veasey - brytyjski fotograf, który prześwietlił aparatem rentgenowskim ponad cztery tysiące obiektów, w tym: samochód, autobus, samolot typu Boeing 777 (obecnie największy prześwietlony obiekt); Satre Stuelke - Amerykanin, prześwietla tomografem przedmioty codziennego użytku i materie organiczne: toster, maszynkę do golenia, krzesło, lampkę, hamburgera, zestaw obiadowy typu fast food itp. W Polsce ten sposób obrazowania wykorzystuje w swoich stereoskopowych pracach Grzegorz Banaszkiewicz. Żaden z wyżej wymienionych artystów nie używa jednak ruchomych obrazów, pozyskanych dzięki tomografowi komputerowemu, do budowania złożonych narracji o filmowym charakterze. Ze względu na ten fakt czuję się upoważniona do sformułowania: „odkryłam nowe medium na terenie video art". 